\title{
Cor da pele, distinções e cargos: Portugal e espaços atlânticos portugueses (séculos XVI a XVIII) ${ }^{12}$
}

João de Figueirôa-Rêgo ${ }^{3}$

Fernanda Olival ${ }^{4}$

Neste texto, analisa-se de que forma o centro político de Lisboa e as elites coloniais lidaram com a realidade da cor no espaço atlântico, sobretudo no que respeitava ao provimento de lugares e, inclusive, no acesso a distinções sociais de patamar intermédio; averigua-se o modo como o centro político fundamentou as suas perspectivas sobre a temática em diversas cronologias; tenta-se também sondar se nalguns locais a existência de sangue nativo no seio dos grupos sociais elevados terá alterado uma percepção simplista das variantes cromáticas. Como a questão abarcou, grosso modo, os tempos fortes (1570-1773) da vigência dos estatutos de pureza de sangue em Portugal, discute-se a possível conexão / contaminação entre essas duas realidades.

Palavras-chave: Miscigenação - cargos seculares - clero

Skin color, distinctions and offices: Portugal and Portuguese Atlantic spaces (XVI to XVIII centuries)

This text shows how the Lisbon political core and the colonial elites dealt with the color issue in the Atlantic space, especially in respect to the provision of places and even to access to intermediate social distinctions; it investigates how the political core based its

\footnotetext{
${ }^{1}$ Artigo recebido e aprovado para publicação em julho de 2010.

2 Trabalho desenvolvido no âmbito do projecto FCT/COMPETE/FEDER: FCOMP-01-0124-FEDER-007360.

${ }^{3}$ Professor do CHAM - Universidade Nova de Lisboa. E-mail: joaofigueiroarego@gmail.com

${ }^{4}$ Professora da Universidade de Évora. E-mail: fernanda.olival@gmail.com
} 
views on that theme in several chronologies; it also surveys whether in some locations the presence of native blood among higher social groups modified a simplistic perception of the chromatic variations. Since the issue covered grosso modo the strong period (15701773) when the blood purity rules were in force in Portugal, it discusses the possible connection / contamination between these two realities.

Keywords: Miscegenation - secular offices - clergy

\section{Couleur de la peau, distinctions et postes: Portugal et les espaces atlantiques portugais (du XVI ${ }^{\mathrm{e}}$ au XVIII ${ }^{\mathrm{e}}$ siècle)}

Dans ce texte nous analysons de quelle façon le centre politique de Lisbonne et les élites coloniales ont traité la réalité de la couleur dans l'espace atlantique, particulièrement en ce qui touche l'attribution des postes et, également, l'accès aux distinctions sociales de niveau intermédiaire; on étudie également la façon dont le centre politique a fondé ses perspectives sur cette thématique dans diverses chronologies: on cherche également à vérifier si dans certains endroits l'existence d'un sang natif au sein des groupes sociaux élevés aurait modifié la perception simpliste des variantes chromatiques. Du fait que la question a englobé, grosso modo, les temps forts (1570-1773) de la durée des statuts de pureté du sang au Portugal, on discute la possible connexion/ contamination entre ces deux réalités. Mots-clé: Metissage - postes séculiers - clergé

Com a expansão marítima dos povos peninsulares, o problema da cor da pele rapidamente ganhou relevância como um tópico que facilmente identificava o não europeu.

A partir do século $\mathrm{XV}$, era cada vez mais raro escravizarem-se os brancos, ao mesmo tempo que os subsaarianos afluíam em número crescente aos portos portugueses; eram trazidos de forma forçada para serem escravos e vendidos em diferentes paragens do mundo atlântico. Em meados do século XVI, constituíam quase $10 \%$ da população de Lisboa. ${ }^{5}$ Simultaneamente, diferentes formas de miscigenação tornaram-se a pouco e pouco um dado evidente, tanto em Portugal, como sobretudo nos territórios coloniais. Além de negro, preto e índio, mestiço, mulato, mameluco, cabra, pardo, baço, crioulo, etíope, guinéu, cafre, fusco, cafuzo,

\footnotetext{
${ }^{5}$ Vitorino Magalhães Godinho, "Lémigration portugaise (XVe-XXe siécles) - une constante structurale et les réponses aux changements du monde", Revista de História Económica e social, Lisboa, $\mathrm{n}^{\circ}$ 1, 1978, pp. 9-10. Sobre as percentagens de misturas raciais em diversos pontos do Império Português, ver: Francisco Bethencourt, "Race relations in the Portuguese Empire”, In: Encompassing the Globe: Portugal and the World in the 16th and 17th Centuries, Washington, Arthur M. Sackler Gallery, Smithsonian Institution, 2007, pp. 45-49.
} 
trigueiro, branco da terra foram algumas das formas vocabulares ${ }^{6}$ para designar não etnias, mas a presença de gente de cor em Portugal e no império atlântico. Desde logo, esta diversidade de denominações, algumas com carácter regional, outras oscilantes em funções de interesses em vista, configura uma dificuldade acrescida quando se pretenda observar o relacionamento sócio-racial. Na época, adjectivar seria, tanto ou mais do que descrever, classificar socialmente.

Se negro ou preto rapidamente se tornaram - por todo o lado - quase sinónimo de escravo, nem sempre era de facto assim. Em S. Tomé, por exemplo, D. João II ordenara que se desse a cada um dos degredados e outras pessoas do início da colonização uma escrava, tendo em vista incentivar o povoamento da Ilha. Mais tarde (1515) surgiu o problema de saber qual o estatuto das pessoas envolvidas e dos filhos resultantes dessas uniões, D. Manuel declarou-as livres, bem como os escravos homens dados a esses europeus (1517). ${ }^{7}$ Desta forma, desde cedo havia nos grupos da base da pirâmide social negros e mulatos livres e outros que não o eram, mesmo em África.

Neste texto pretende-se analisar de que forma o centro político de Lisboa e as elites coloniais lidaram com a realidade da cor no espaço atlântico, sobretudo no que respeitava ao provimento de lugares e, indirectamente, no acesso a distinções sociais. Importará também apurar se nalguns locais a existência de sangue nativo no seio dos grupos sociais mais elevados terá alterado uma percepção simplista das variantes cromáticas.

Não se trata obviamente de uma questão nova na historiografia que versa o Atlântico. Desde logo, sobre o assunto podem considerar-se como marcantes alguns textos clássicos de C. R. Boxer ${ }^{8}$ e de A. J. R. Russell-Wood. ${ }^{9}$ É também uma

\footnotetext{
${ }^{6}$ Sobre o significado de algumas destas variantes designativas, Marcus Vinicius Fonseca, Pretos, pardos, crioulos e cabras nas escolas mineiras do século XIX. São Paulo, Tese de Doutoramento em Educação apresentada à Faculdade de Educação, Universidade de São Paulo, 2007 e Jocélio Teles dos Santos, "De pardos disfarçados a brancos pouco claros: classificações raciais no Brasil dos séculos XVIII-XIX”, Afro-Ásia, no 32, 2004, pp. 115-137. Stuart B. Schwartz, "Brazilian ethnogenesis: mestiços, mamelucos and pardos”, In: Serge Gruzinski e Nathan Wachtel (eds.), Le nouveau monde, mondes nouveaux: l'expérience américaine: actes du colloque, Paris, EHESS, 1996, pp. 7-27.

${ }^{7}$ Padre António Brásio (comp. e anot.), Monumenta missionaria Africana: África Ocidental, vol.I, Lisboa, Agência-Geral do Ultramar, 1952, pp. 331-332, 376.

${ }^{8}$ Relações raciais no Império colonial Português 1415-1825, Porto, Afrontamento, 1977.

${ }^{9}$ Em particular: "Local government in Portuguese America: a study in cultural divergence", Comparative Studies in Society and History, Cambridge, vol. 16, n 2, 1974, pp. 187-231; "Ambivalent Authorities: The African and Afro-Brazilian Contribution to Local Governance in Colonial Brazil", The Americas, vol. 57, n. 1, Jul. 2000, pp. 13-36.
} 
área a que a historiografia brasileira e a que se produz sobre o Brasil tem dado crescente atenção nos últimos anos.

Ao revisitar esta problemática, o que se procura abordar é sobretudo o modo como o centro político fundamentou as suas perspectivas sobre a temática em diversas cronologias e conjunturas. Note-se que grosso modo abarca os tempos fortes (1570-1773) da vigência dos estatutos de pureza de sangue em Portugal. Na realidade, aspira-se ainda a discutir a possível conexão / contaminação entre estas duas realidades.

\section{Provimentos seculares}

O provimento de cargos para o Império - fossem eles eclesiásticos, administrativo-judiciais ou militares - constituía um momento importante da apreciação da cotação social e política dos indivíduos a quem se atribuía tal função.

No caso dos lugares de governadores e capitães-mores, esse facto tornou-se mais visível a partir de 1643, quando a tendência passou a ser cada vez mais o preenchimento dos postos mediante concurso, nas situações normais. Quando havia uma vacatura, depois de um prazo para a apresentação de candidaturas, cabia ao Conselho Ultramarino pronunciar-se sobre o perfil dos mais votados. A consulta em causa podia - inclusive - passar pelo crivo do Conselho de Estado, quando respeitante aos governos mais importantes. ${ }^{10}$ Nestes textos, fundamentavam-se escolhas, discutiam-se critérios e avaliavam-se percursos. No entanto, na América portuguesa, como possivelmente nos restantes locais do Atlântico, a tendência para serem nomeados de reinóis (os naturais foram apenas $22 \%$ no século XVII e $10 \%$ na centúria seguinte) que estivessem acima dos interesses locais ${ }^{11}$ e assegurassem o domínio simbólico da Metrópole. Mesmo quando iam parar a gente da terra, tendiam a recair na principalidade ou em membros das elites locais e a questão dos ascendentes pouco interferia. O caso dos Albuquerques, com sangue índio nas suas origens, é bem expressivo. Os serviços prestados na defesa do Brasil tinham maior cotação e ajudaram a conquistar estatuto social.

\footnotetext{
${ }^{10}$ Mafalda Soares da Cunha, Nuno Gonçalo Monteiro, “Governadores e capitães-mores do Império atlântico português nos séculos XVII e XVIII", In: Nuno Gonçalo Monteiro, Pedro Cardim, Mafalda Soares da Cunha (org.), Optima pars: elites ibero-americanas do Antigo Regime, Lisboa, ICS, 2005, pp. 211-212.

${ }^{11}$ Idem, Idem, Ibidem, pp. 241-242.
} 
A linha dominante era, no entanto, para não se descurar facilmente este último aspecto. Na segunda metade do século XVII havia a pretensão de que os seleccionados para governadores teriam de usufruir do foro de fidalgo da Casa Real. Em Janeiro de 1692, perante dificuldades em encontrar pessoas adequadas para os governos extraeuropeus o peso do estatuto social tornou-se marcante. $\mathrm{Na}$ ocasião, o Secretário de Estado Mendo de Fóios Pereira comunicou ao Conselho Ultramarino o seguinte: "Sua Majestade me ordenou dissesse (...) que o Conselho poderia consultar dispensando antes na falta de serviços que na qualidade". ${ }^{12}$ No entanto, no ano seguinte, o Conselho Ultramarino já recebia autorização para indicar para o governo de Cabo Verde gente sem o referido foro, pois não havia opositores que o tivessem. ${ }^{13}$

Desta forma, a questão da cor estava, no entanto, mais presente nas questões de política local, onde ser branco se transformava numa primeira forma de distinção.

Nessa escala, a historiografia registou, com alguma frequência, episódios de animadas diatribes e acérrimas disputas entre elites reinóis e grupos crioulos. ${ }^{14}$ No geral, tais dissensões foram entendidas como reflexo, ou indicador, de uma alegada menorização dos "filhos da terra", mercê de conotações simbólicas negativas. Resultariam estas do associar, por exemplo, cor e escravatura, cor e ilegitimidade de nascimento (muitas vezes fruto de adultério) ou, ainda, mestiçagem e vadiagem. ${ }^{15}$ Embora essa visão relacional configurasse, na prática, um obstáculo à legitimação social dos grupos miscigenados (face ao quadro mental imperante), a verdade é que outros elementos contribuíram para um certo extremar de posições. Assim, parecem indissociáveis de toda essa trama questões de índole socioeconómica, de pendor político, ou até meramente circunstanciais. Quando, por exemplo, em finais do século XVI e inícios do século XVII, o arquipélago de Cabo Verde foi ultrapassado no seu estatuto de feitoria do Atlântico,

\footnotetext{
${ }^{12}$ ANTT, Manuscritos do Brasil, L ${ }^{\circ} 33$, fl.153.

${ }^{13}$ Ibidem, fl. 169v-170.

${ }^{14}$ Ver, a esse propósito, Zelinda Cohen, Controle e resistência no quadro do funcionalismo régio insular (Cabo Verde, séculos XV a meados do XVIII), Lisboa, FCSH/UNL, 1999.

${ }^{15}$ Sobretudo no sentido subversivo com que foi usada, cf. Maria João Soares, "Crioulos Indómitos' e Vadios: Identidade e Crioulização em Cabo Verde - Séculos XVII-XVIII", In: Actas do Congresso Internacional Espaço Atlântico de Antigo Regime: poderes e sociedades, Lisboa, CHAM, 2005 e Renato Franco, "Hierarquia e diferenciação social na América Portuguesa, século XVIII", p. 7, texto disponível on-line em: http://www.neps.ics.uminho.pt/aphes28/papers/Renato\%20Franco. pdf. Consulta em 1 de Dezembro de 2009.
} 
observou-se uma quebra da dinâmica comercial com a consequente deslocação dos centros de trocas até aí preponderantes. Tal facto conduziu a um abandono gradual dos negócios e interesses fundiários, por parte dos agentes (de extracção reinol) sediados naquelas ilhas. ${ }^{16}$ Com a retirada destes para o Reino, ou para outras plataformas comerciais mais atractivas, coube aos crioulos chamar a si a manutenção dos patrimónios gerados, bem como contribuir para o incremento da produção autóctone. $\mathrm{O}$ grupo crioulo, na sua maioria gerado na miscigenação ilegítima, passou, desse modo, a usufruir de um estatuto destacado e interventivo. Essa mudança, com a emergência de novos actores, criou, inevitavelmente, resistências e focos de disputa. Como, aliás, parece poder deduzir-se do teor de inúmeros protestos e consultas da Câmara da Ribeira Grande. ${ }^{17}$ Em sinal do mal estar gerado, uma decisão emanada do centro político determinou, em 1620, fazer deslocar para Cabo Verde as mulheres (brancas) comummente degradas para o Brasil, no intuito de que "se extinga, quanto possível, a raça dos mulatos". ${ }^{18}$

No caso do Brasil, há que ter em conta a sua diversidade de territórios, sob os mais variados pontos de vista. Na zona de Minas Gerais, apesar do surto da criação de câmaras se ter concentrado por volta de 1710-1711, a elitização das mesmas ocorreu a meados do decénio seguinte, trazendo à colação o problema da cor da pele. ${ }^{19}$ No início, não havia gente adequada a ocupar os postos municipais e os mecânicos, e os mulatos puderam exercê-los, tendo tudo mudado posteriormente. ${ }^{20}$

Em 1723, era o próprio governador de Minas a propor uma lei que excluísse os mulatos da herança paterna, não lhes permitindo sequer receber lega-

\footnotetext{
${ }^{16}$ Philip Havik, "Missionários e Moradores na Costa da Guiné. Os padres da Companhia de Jesus e os tangomãos no princípio do século XVII”, Studia, no 56/7, 2000, p. 223/61.

${ }^{17}$ Carlos Almeida, "A Companhia de Jesus e a sociedade crioula Cabo-Verdiana na primeira metade de Seiscentos - uma história de desencontros", In: Avelino de Freitas Meneses, João Paulo Oliveira Costa (coord.), O reino, as ilhas e o mar oceano. Estudos em homenagem a Artur Teodoro de Matos, CHAM, vol. 2, p. 537.

${ }^{18}$ Christiano José de Senna Barcellos, Subsídios para a História de Cabo Verde e Guiné (Parte I), Academia Real das Ciências, Lisboa, 1899, p. 210.

${ }^{19}$ Ver por exemplo, para o caso do Rio de Janeiro, os estudos de João Fragoso, "A nobreza da República: notas sobre a formação da primeira elite senhorial do Rio de Janeiro (séculos XVI e XVII)", Topoi, Rio de Janeiro, n. 1, pp. 45-122 e Fernanda Bicalho, "As Câmaras Municipais no Império Português: o exemplo do Rio de Janeiro", Revista Brasileira de História, vol. 18, n. 36, 1998. Para Pernambuco, Janaína Santos Bezerra, Pardos na cor \& impuros no sangue: etnia, sociabilidades e lutas por inclusão social no espaço urbano pernambucano do XVIII, Recife, Universidade Federal Rural de Pernambuco, 2010.
}

${ }^{20}$ A. J. R. Russell-Wood, “Local government in Portuguese America”, op. cit., pp. 198-199. 
dos testamentários. Se não houvesse herdeiros tais bens deviam ir parar ao fisco, "como deixados às pessoas indignas", segundo opinava o procurador da Coroa. A maior parte dos membros do Conselho Ultramarino terá anuído à proposta, apenas permitindo que os pais legassem a estes filhos de cor uma módica quantia de alimentos regulada "somente para que não pereçam" e não admitindo que se pudesse deixar alguma coisa às mães. Houve, contudo, votos fundamentados contra. Num desses, apontava-se com clareza que eram ditames que se opunham ao estabelecido nas Ordenações do Reino (Ord. Fil., L ${ }^{\circ}$ IV, tít. 92) e que seria castigar os filhos pela culpa do pai. ${ }^{21} \mathrm{~A}$ lei não terá sido feita.

No entanto, as elites locais não paravam de pressionar para que houvesse maior obstáculo à mobilidade social dos miscigenados. Pretendiam embargar cargos na governança municipal naquela capitania a indivíduos de ascendência africana até ao $4^{\circ}$ grau: "Dentro nos quatro graus em que o mulatismo é impedimento, e da mesma sorte não possa ser eleito o que não for casado com mulher branca, ou viúvo dela." Assim foi estabelecido pela Coroa em 1726, na sequência de uma consulta do Conselho Ultramarino. ${ }^{22} \mathrm{Na}$ realidade, ainda que o estigma da mulatice e irregularidade de nascimento pudesse servir de elemento de caracterização depreciativa, o que estaria manifestamente em causa seriam dois aspectos. Em primeiro lugar, a perturbação introduzida no quotidiano pelas aspirações e interesses desses grupos. Os defeitos imputados apenas acentuavam graus de incompatibilidade tecidos na rivalidade e em clivagens de afirmação social e identitária, que se projectavam para lá da singularidade cromática e dos acidentes de nascença. Em segundo lugar, a vivência da cor da pele branca como um factor de promoção das terras e como um defeito, semelhante à questão do sangue cristão-novo ou mouro. Não era por acaso que a Consulta do Conselho Ultramarino que tratara do assunto se justificava: "Era justo que somente as pessoas que tivessem esta qualidade ["limpo nascimento" equivalente a cor branca] fossem eleitas para servir de vereadores e andar na governança delas, porque se a falta de pessoas capazes fez a princípio necessária a tolerância de admitir os mulatos ao exercício daqueles ofícios, hoje tem cessado esta razão, se faz indecoroso que eles sejam ocupados por pessoas em que haja semelhante defeito."23

\footnotetext{
${ }^{21}$ AHU, Conselho Ultramarino, Minas Gerais, Cx. 4, doc. 37.

${ }^{22}$ Idem, Cx. 7, doc. 26.

${ }^{23}$ Ibidem.
} 
Minas não foi, contudo, um caso particular, mercê das circunstâncias resultantes da exploração aurífera, que a levou a ter - em meados do século XVIII - a maior concentração populacional da América Portuguesa e nesta 50\% eram gentes de origem africana. ${ }^{24}$ Em relação ao Rio de Janeiro, por exemplo, sabe-se que em 1678 os oficiais da câmara daquela cidade solicitaram, junto da Coroa, o privilégio para que os naturais ou principais da terra tivessem prioridade nos cargos da dita câmara, em detrimento dos reinóis. ${ }^{25}$ Por volta de 1730, afirmava-se, no Rio Grande do Norte, "que os mestiços, pelas suas qualidades e inclinação para a indisciplina, eram inaptos para desempenhar funções na administração pública”. ${ }^{26}$ Em 1732, o capitão-mor do Rio Grande do Norte, João de Barros Braga, em carta ao rei D. João V, insurgia-se ainda contra o costume local de permitir a ocupação de cargos públicos por mulatos e mamelucos, devido à falta de homens brancos. ${ }^{27}$

Aqui e ali no Brasil, a cor era também interpretada como associada a características psicossomáticas que induziriam à prática de actos desonesto ${ }^{28} \mathrm{e}$ violentos. ${ }^{29} \mathrm{~A}$ insegurança causada por comportamentos agressivos de pardos e mulatos, bem como a necessidade das elites coloniais demarcarem o seu próprio espaço, face a origens e atitudes questionáveis (promiscuidade sexual, concubinatos e bastardias), fomentaram grande sensibilidade no tocante a hierarquias baseadas em critérios de cor. Tanto mais que, ao contrário do exemplo da América castelhana, a posse de signos de distinção (institutos vinculares, cartas de

${ }^{24}$ Virgínia Maria Trindade Valadares, Elites Mineiras Setecentistas. Conjugação de dois mundos, Lisboa, Colibri, 2004, p. 270. Sobre as especificidades da sociedade de Minas, Laura de Mello e Souza, O sol e a sombra: política e administração na América portuguesa do século XVIII, São Paulo, Companhia das Letras, 2006, pp. 148-181.

${ }^{25}$ Maria Fernanda Bicalho, "As câmaras ultramarinas e o governo do Império" In: João Fragoso, Maria Fernanda Bicalho, Maria de Fátima Gouvêa (orgs.), O antigo regime nos trópicos: a dinâmica imperial portuguesa (séculos XVI-XVIII), Rio de Janeiro, Civilização Brasileira, 2001, p. 218.

${ }^{26}$ Stuart B. Schwartz, Da América Portuguesa ao Brasil, Lisboa, Difel, 2003, p. 236.

${ }^{27}$ AHU, Conselho Ultramarino, Rio Grande do Norte, Cx. 3, doc. 18.

${ }^{28}$ Como se colhe, por exemplo, de uma carta de 1757, do ouvidor-geral da Paraíba, Domingos Monteiro da Rocha, ao rei D. José I, sobre a Correição em Itamaracá, onde encontrou o escrivão António da Fonseca com os livros da distribuição criminal adiantado em mais de vinte devassas e queixando-se da desonestidade do citado escrivão, mulato e liberto - AHU, Conselho Ultramarino, Paraíba, Cx. 20, doc. 1527.

${ }^{29}$ AHU, Conselho Ultramarino, Minas Gerais, Cx 16, doc. 78. 
armas de fidalguia, hábitos de ordens militares e filhamentos da Casa Real) era assaz diminuta. Perante a rarefacção de insígnias nobilitantes, os grupos privilegiados, "abastados em riquezas e faltos de mercês e honras", ${ }^{30}$ tendiam a buscar no distintivo da cor um ponto de partida para a distinção. Era o primeiro nível dessa hierarquia. Em 1757, Domingos Loreto Couto exprimia essa realidade: "Não é fácil determinar nestas Províncias quais sejam os homens da Plebe; porque todo aquele que é branco na cor entende estar fora da esfera vulgar. Na sua opinião, o mesmo é ser alvo, que ser nobre, nem porque exercitem ofícios mecânicos perdem esta presunção." ${ }^{11}$

As directivas da Coroa nem sempre eram consoantes com os interesses locais e com as classificações forjadas nesse contexto, mesmo para o Brasil..$^{32}$

Em 1731, por exemplo, D. João V ordenou ao Governador da Capitania de Pernambuco, Duarte Sodré Pereira, que empossasse o mulato António Ferreira de Castro no cargo de Procurador da Coroa. Na carta régia, afirmava-se, de modo peremptório, que a cor não servia de impedimento para exercer tal função, para mais tratando-se de um bacharel. O monarca invectivava até Sodré Pereira que se viu obrigado a justificar-se. ${ }^{33}$ Com efeito, teria levantado objecções a uma determinação régia anterior, feita no mesmo sentido, e procurado atribuir o cargo a alguém que, embora branco, seria desprovido de habilitações. Os termos da censura eram explícitos: "Tendo entendido que não tivestes justa razão para replicardes a ela, porquanto o defeito, que dizeis haver no dito provido por este acidente excluísses um Bacharel Formado provido por mim para introduzirdes e

${ }^{30}$ Domingos de Abreu Pinto, Um inquérito à vida administrativa e económica de Angola e do Brasil em fins do século XVI, segundo o manuscrito inédito existente na Biblioteca Nacional de Lisboa, publicação revista e prefaciada por Alfredo de Albuquerque Felner, Coimbra, Imprensa da Universidade, 1931, p. 9.

31 "Desagravo do Brasil e glória de Pernambuco", Anais da Biblioteca Nacional, Rio de Janeiro, vol. 24, 1904, p. 227.

${ }^{32}$ Ver, a propósito, Maria de Fátima Silva Gouvêa, Gabriel Almeida Frazão, Marília Nogueira dos Santos, "Redes de poder e conhecimento na governação do Império Português, 1688 -1735", Topoi, vol. 5, n. 8, jan.-jun. 2004, pp. 96-137; Renato Marinho Brandão Santos, "A sociedade do pacto: elementos de coesão social no império português (XVII-XVIII)”, DOMINIUM, Ano VII Vol 1. Jan/Abr 2009; Marília Nogueira dos Santos, “O império na ponta da pena: cartas e regimentos dos governadores-gerais do Brasil”, Tempo, vol.14, n.27, 2009, pp. 101-117.

${ }^{33}$ Ver a resposta do governador ao Rei justificando as razões que tivera para não efectuar a posse, AHU, Pernambuco, Cx. 42, doc. 3803. 
conservares um homem, que não é formado, o qual nunca o podia ser pela Lei, havendo Bacharel Formado." ${ }^{34}$

Neste caso, como noutras contendas abertas localmente, foi ao centro político que coube o papel de mediador. ${ }^{35}$

Do mesmo modo, e a despeito das aparências, nem sempre as disposições normativas seriam integralmente respeitadas de parte a parte. Gerava-se assim, e a pouco e pouco, mais do que um quadro de referência. Como estes podiam coexistir, originavam espaços de fluidez e acobertavam um modus vivendi com regras muito próprias.

Acresce que a Coroa não actuava do mesmo modo em relação a todos os territórios coloniais.

Em São Tomé, por exemplo, a mestiçagem foi incentivada pela Coroa desde os finais do século XV. A legitimação dos mulatos e, consequentemente, a sua capacidade de suceder nos bens patrimoniais possibilitaram que, desde 1520, os mestiços pudessem servir ofícios da Câmara. Uma provisão régia de 1546 foi ainda mais longe e nela, D. João III confirmou aos "pardos filhos das ilhas" o direito de ocuparem cargos de administração e milícia, em plena igualdade com os brancos. ${ }^{36} \mathrm{Na}$ realidade já assim era desde 1528, quando D. João III permitiu que "os mulatos moradores na dita Ilha, que forem homens de bem e casados e pertencentes pera isto, emtrem nos ofiçios do Conçelho, segundo seus merecimentos". A mesma carta corrobora que não se tratava de uma situação nova: "Como nos é dito que sempre andaram, sem embargo do capitão o vedar". ${ }^{37}$

Fora deste sector, dever-se-á assinalar que os cargos de nomeação régia mais relevantes só timidamente foram atribuídos ao grupo mestiço / negro, até porque não tendiam a recair em naturais do arquipélago.

\footnotetext{
${ }^{34}$ Roberta Fragoso de Menezes Kaufmann, Ações afirmativas à brasileira: necessidade ou mito? A implementação de políticas afirmativas para negros como mecanismo concretizador de direitos fundamentais. Uma análise histórico-jurídico-comparativa do negro nos Estados Unidos da América e no Brasil, Porto Alegre, Livraria dos Advogados, 2007. Disponível on-line em: http://www1. jus.com.br/doutrina/texto.asp? id=10070, consultado em 1 de Dezembro de 2009.

${ }^{35}$ Um outro exemplo de 1762-1764, no qual o Coroa interveio legislando, AHU, Conselho Ultramarino, Minas Gerais, Cx. 80, doc. 70.

${ }^{36}$ Arlindo Manuel Caldeira, "A questão do protonacionalismo em São Tomé e Príncipe nos séculos XVII e XVIII”, Anais de História de Além-Mar, vol. II, 2001, p. 301.

${ }^{37}$ Padre António Brásio (comp. e anot.), op. cit., vol.I, pp. 500-501.
} 
No entanto, o estigma da ascendência africana (conotada com escravidão) pouco afectaria as elites locais santomenses, eufemísticamente designadas, tal como em Cabo Verde e noutras paragens, por "brancos da terra". ${ }^{38}$ Em 1699, foi eleito para porteiro do concelho um negro. Todavia, os negros forros, destituídos de capacidade patrimonial, tiveram, no geral, de esperar pelo século XVIII para poderem aceder à categoria de "moradores", mediante a qual se lhes abria a possibilidade de integrar o elenco municipal. Tanto assim que, por finais daquela centúria, o capitãomor de São Tomé, João Ferreira Guimarães, em carta a D. Maria I, manifestava certa indignação pelo facto do senado camarário ser formado somente por pretos e mulatos. Conhecedora do facto, a edilidade escreveu à Rainha e, em tom de rematada ironia, sublinhava: "Como se V. Majestade não soubesse que os seus vassalos destas conquistas são destas cores e que as Câmaras sempre assim foram." 39

Apesar do que foi dito, o próprio cargo cimeiro do arquipélago chegou a registar a presença de sangue africano. Como assinalou Arlindo Caldeira, entre 1600 a 1750 , aquelas ilhas teriam estado sem governo nomeado pelo menos cerca de 23 vezes. ${ }^{40}$ Como tais provimentos eram morosos e dependentes inclusive da negociação de contrapartidas para aqueles que se dispunham a ir servir em paragens tão inóspitas, o expediente encontrado fora o de entregar ao executivo camarário a condução dos negócios político-administrativos. Em geral, no século XVII, o senado escolhia para o efeito um notável local e na centúria seguinte assumia o cargo de forma colectiva.

Como se depreende, estas ocasiões serviriam para angariar vantagens mesmo que isso significasse extravasar limites impostos. Uma das consequências resultantes consistiria na possibilidade do mandatado (possidente eleito ou câmara) prover abusivamente ofícios em gente da sua parcialidade, nem que para tal tivessem de demitir os que estavam em exercício. Tudo isso configurava uma janela de oportunidades para as elites mestiças. Porém, como é óbvio, acicatava inúmeras rivalidades e demarcava, ainda mais, a fronteira entre mulatos privilegiados e brancos e pretos pobres. Facto que o centro político não ignorava, como prova

\footnotetext{
38 “(...) [A]inda que se posa diser não há homens brancos do Reino, e sim brancos da terra (...) e propriamente sejao mulatos, e muitos pretos”, excerto de uma carta enviada ao rei pelo ouvidor José da Costa Ribeiro, datada de 16 de abril de 1731, cf. AHU, CV, cx. 14, docs 27 e 28.

${ }^{39}$ Carlos Agostinho das Neves, S. Tomé e Príncipe na $2^{a}$ metade do século XVIII, Funchal/Lisboa, Secretaria Geral do Turismo/ Instituto de História de Além-Mar, 1989, p. 441.

${ }^{40}$ Arlindo Manuel Caldeira, art. cit., p. 305.
} 
uma consulta do Conselho Ultramarino, datada de 1638, na qual se alude aos danos que disso resultava à Coroa. ${ }^{41}$

Emblemático do tipo de desmandos que podiam ocorrer no decurso desses interregnos foi o sucedido com João Álvares da Cunha, grande proprietário mulato. Em 1683, por morte do governador nomeado pelo Reino, dois juízes ordinários propuseram ao dito terratenente (possuidor da melhor roça à época e dono de 300 escravos) que aceitasse o governo da ilha. Face à recusa de alguns membros do senado da câmara de sancionar a escolha, o nomeado não hesitou em mandálos prender, bem como ao próprio ouvidor régio. Álvares da Cunha exerceu o governo e a ouvidoria de forma parcial e despótica praticando inúmeras tropelias "contra todo o direito das gentes e despozições (...) pondo em tal estado e perturbação aquella Ilha que os moradores brancos que aly hauia (...) se retirarão pera as suas fazendas" ${ }^{42}$ Durou isto até 1686 , altura em que um novo governador enviado do Reino o mandou agrilhoar e remeter sob prisão para Lisboa. ${ }^{43}$

Já quanto aos postos militares de companhias de ordenanças, ${ }^{44}$ inicialmente ocupados por brancos, ${ }^{45}$ foram, a partir de inícios do século XVIII, servidos por "filhos da terra". ${ }^{46} \mathrm{O}$ que, aliás, seria consentâneo com a exiguidade de reinóis e a composição das gentes locais.

Também no Brasil, existiria grande tolerância no tocante à cor, sobretudo nas tropas regulares. Ali, segundo parece, o recrutamento só deixava de fora pretos e mulatos muito escuros. ${ }^{47}$ Os restantes serviam lado a lado com os brancos, sem distinção, embora pudessem ser menos favorecidos no tocante a promoções e dispensas. ${ }^{48}$ Contudo, essa aparente integração teria uma finalidade subjacente

${ }^{41}$ AHU, São Tomé, Cx. 3, n. 68, apud Cristina M. Seuanes Serafim, As ilhas de S. Tomé no século XVII, Lisboa, CHAM, 2000, p. 62.

${ }^{42}$ AHU, Conselho Ultraarino, Cód. 478, fl. 102-103.

${ }^{43}$ Manuel do Rosário Pinto, op. cit. pp. 145-147.

${ }^{44}$ Para o caso do Brasil ver Ana Paula Pereira Costa, “Homens de Qualidade’: a caracterização social das chefias militares dos Corpos de Ordenanças em Minas colonial”, Militares e Política, n. 2 (2008), pp. 7-30.

${ }^{45}$ AHU, S. Tomé, Cx. 4, n. 83, apud Ana Paula Pereira Costa, op. cit., p. 95.

${ }^{46}$ Ibidem.

${ }^{47}$ Caio Prado Jr., Formação do Brasil Contemporâneo. São Paulo, Editora Brasiliense, 23a edição, 1994, p. 310, apud GOMES, José Eudes Arrais Barroso, As Milícias d'El Rey: tropas militares e poder no Ceará setecentista, Niterói, Universidade Federal Fluminense, 2009, p. 85.

${ }^{48}$ C. R. Boxer, op. cit., p. 117. 
"porque não convém que semelhantes homens sirvam em companhia ou corpo separado dos demais, pois o que servia obrar em tal caso, era misturá-los com os demais corpos das ordenanças dos homens brancos, para ficarem mais sujeitos e obedientes", ${ }^{49}$ lia-se numa ordem de 27 de Janeiro de 1728.

Por finais de setecentos, a mobilidade dos pardos no meio castrense era evidente visto sua nomeação para patentes elevadas, como mestre de campo e sargento-mor. ${ }^{50}$ Todavia, existiam ainda alguns limites à miscigenação, por questões de decoro social. Em 1771, por exemplo, o então vice-rei do Brasil, Marquês de Lavradio, exonerou um índio que ocupava o posto de capitão-mor por haver casado com uma preta, "manchando o seu sangue com esta aliança", e tornando-se assim indigno de exercer o cargo. ${ }^{51}$

Em matéria de provimento/exercício de cargos seculares, numa macro escala de observação, em relação a Cabo Verde o quadro seria semelhante ao registado em S. Tomé. Também, ali no século XVI, os moradores de Santiago "filhos da terra”, incluindo brancos e pretos, podiam aceder aos ofícios concedidos, por mercê de D. João III (ainda que, na prática, tal medida só tenha tido efeito significativo quando o contingente de brancos se tornou insuficiente). No entanto, face à dificuldade sentida pela Coroa de exercer um controlo eficaz sobre o território e subtraí-lo à influência das oligarquias instaladas, gerou-se uma forte ligação, através dos oficiais régios, entre os grupos mestiços e o centro político. Nesse sentido, convirá realçar o papel do corregedor, dada a sua centralidade no contexto do aparelho político-administrativo e enquanto elemento de articulação entre instituições e poderes insulares e metropolitanos. Significativamente terá sido nos grupos baços e pretos que esses funcionários régios encontraram maior

\footnotetext{
${ }^{49}$ Francis Cotta, "Os Terços de Homens Pardos e Pretos Libertos: mobilidade social via postos militares nas Minas do século XVIII”, Mneme, vol. 3. n. 6 de out./nov. de 2002, p. 79.

${ }^{50}$ Em 1751, o então vice-rei do Brasil, conde de Atouguia, em carta a Diogo de Mendonça Corte Real escrevia: "Os postos de que trata a carta de V. Ex. ${ }^{a}$ e a consulta do Conselho são o de Capitão de uma companhia, que aqui há de Ordenanças, composta de mulatos e se costuma prover em um mulato e mulato era o último que o governava; outro de Sargento Mór dos assaltos e entrada do mato, cujo exercício é ir ao mesmo prender os negros fugidos a seu Sr. e retirados do mato, e também é estilo conferir-se a um mulato ou negro", cf. Eduardo de Castro e Almeida, Inventário dos documentos relativos ao Brasil existentes no Arquivo de Marinha e Ultramar, VIII, Rio de Janeiro 1747-1755, Anais da Biblioteca Nacional, Rio de Janeiro, vol. 31, 1913, p. 6.

${ }^{51}$ Gilberto Freyre, Casa Grande \& Senzala. Formação da Família Brasileira sob o regime de economia patriarcal, Lisboa, Livros do Brasil, s/d, p. 396.
} 
apoio, contra os interesses estabelecidos. Muito embora, sublinhe-se, nem sempre a sua acção fosse pacífica ou um pilar de estabilidade, dando mesmo origem a "coligações aleatórias", constituídas em função de conveniências particulares. ${ }^{52}$

De qualquer modo, a despeito das incongruências e dificuldades do sistema, parece que no início do século XVII os "filhos da terra" (mulatos e negros) ocupavam já, em Cabo Verde, os espaços sociais anteriormente preenchidos pelos reinóis, de quem muitos deles eram descendentes ilegítimos. ${ }^{53}$ Tratava-se de uma nova elite, essencialmente urbana e cosmopolita, de que será exemplo o mulato André Álvares de Almada, que recebeu a mercê do hábito da Ordem de Cristo, apesar de ser mestiço. Pelos seus serviços na defesa da Ilha, enquanto capitão de uma companhia, o "defeito de sangue" foi relevado em $1598 .{ }^{54}$

A terceira elite geracional, que cronologicamente coincidia com a segunda metade do século XVII, ${ }^{55}$ era endógena, mestiça e, claramente, de matriz caboverdiana. Formavam-na os chamados "brancos da terra" (maioritariamente mulatos e pretos), ${ }^{56}$ o que levou o governador Juzarte de Santa Maria a reconhecer, em 1749 , que "os desta ilha que têm este nome de brancos e não o são". Contudo, tratava-se de um grupo de grandes proprietários rurais que, com o desvio definitivo do tráfico de escravos, voltaram-se para o interior da ilha "onde adquiriam rendas advindas da exploração da terra e da comercialização de produtos agrícolas

\footnotetext{
${ }^{52}$ Dever-se-á realçar, também nesse contexto, a função dos ouvidores e dos juízes de fora mesmo em territórios como o Brasil. Ver a propósito as considerações e casos enunciados, respectivamente, por Isabele de Matos P. de Mello, Administração, justiça e poder: os Ouvidores Gerais e suas correições na cidade do Rio de Janeiro (1624-1696), Niterói, Universidade Federal Fluminense, 2009; Caio Figueiredo Fernandes Adan, "Ouvidores e camerários na colonial comarca de ilhéus (17501777)” e Suely Creusa Cordeiro de Almeida, "As peripécias dos magistrados: Juízes-de-fora e um cotidiano nada tranquilo entre Recife e Olinda", ambos em Mneme - revista de humanidades, vol. 9. n. 24, Set/out. 2008.

${ }^{53}$ Iva Cabral, "Elites atlânticas: Ribeira Grande do Cabo Verde (séculos XVI-XVIII)”, In: Actas do Congresso Internacional Espaço Atlântico de Antigo Regime: poderes e sociedades, Lisboa, CHAM, 2005.

${ }^{54}$ Era neto de uma mulher preta e filho de uma parda cujo pai foi um nobre e principal da ilha de Santiago - Ilidio Cabral Baleno, "Pressões externas. Reacções ao corso e à pirataria", In: História Geral de Cabo Verde, II, Maria Emília Madeira Santos (coord.), Lisboa / Praia, CEHCA - IICT / Inst. Nacional da Cultura de Cabo Verde, 1995, pp. 176-177.

${ }^{55}$ CABRAL, Iva, "Politica e sociedade: ascensão e queda de uma elite endógena", In: SANTOS, Maria Emília Madeira (coord.), História Geral de Cabo Verde, cit., vol. III.

${ }^{56}$ Ver sobre esse assunto a carta do ouvidor José da Costa Ribeiro datada de 16 de abril de 1731, AHU, Cabo Verde, Papéis Avulsos, cx. 14, doc. 27.
} 
e manufactureiros aos navios que ali aportavam para fazer aguada". ${ }^{57}$ Enquanto "nobreza da terra" chamaram a si o controlo de todas as instituições do poder local em Santiago, desde a câmara à milícia, passando pela Misericórdia; ocuparam, igualmente, todos os ofícios de segundo escalão da administração régia, mau grado as críticas que suscitavam. Em 1753, por exemplo, um desembargador sindicante enviado a S. Nicolau, atribuía à falta de elite letrada o descalabro da Fazenda Real naquela ilha: "Se os officiaes - lamentava o magistrado - fossem outra casta de gente, sam pretos, e tem fácil desculpa na sua ignorância." ${ }^{58}$

À semelhança do já apontado para São Tomé, "os brancos da terra" detiveram, repetidamente (principalmente no século XVIII), todo o poder administrativo e militar das ilhas de Cabo Verde, por via dos interregnos de nomeação que faziam transitar para a Câmara o governo do arquipélago. ${ }^{59}$ Não pode ser alheada desde facto a componente étnica da população. A partir de 1731, verificava-se "um claro predomínio dos mestiços, um peso intermédio de negros e uma percentagem muito diminuta de brancos". ${ }^{60}$

Os percursos de João Pereira de Carvalho, natural de Vila Real de Trás-osMontes, e do seu filho António de Barros Bezerra ilustram bem esse domínio e as atitudes da Coroa em relação ao tópico dos "brancos da terra". João Pereira de Carvalho casara-se em Cabo Verde com uma mulata, descendente de André Álvares de Almada. Tornou-se num homem poderoso, tendo atingido o posto de coronel de infantaria e capitão-mor da vila da Praia, além de ter sido juiz ordinário e vereador, irmão da Misericórdia e governador interino em 1725. Pelos serviços militares que fez em Cabo Verde, entre 1716 e 1727, que incluíam o governo de armas do arquipélago, recebeu a mercê do hábito de Cristo e 40.000 réis de tença em 1732. Feitas as habilitações no ano seguinte, a Mesa da Consciência só o incomodou com as mecânicas que tinha: o pai fora cutileiro e depois estanqueiro e rendeiro; o avô paterno trabalhador e o materno sombreireiro. Pelos serviços que acumulara foi dispensado (cassaram-lhe apenas os serviços

\footnotetext{
${ }^{57}$ Iva Cabral, "Elites atlânticas...”, op. cit.

${ }^{58}$ AHU, Cabo Verde, cx. 34, doc. 37 apud André Pinto de Sousa Dias Teixeira, A Ilha de São Nicolau de Cabo Verde nos séculos XV a XVIII, Lisboa, CHAM, 2004, p. 170/1. Essa analogia entre cor e falta de conhecimento era, por vezes, exagerada intencionalmente pelos magistrados. Ao que parece, servia o propósito claro de desvalorizar certos antagonismos.

${ }^{59}$ Iva Cabral, op. cit.

${ }^{60}$ André Pinto de Sousa Dias Teixeira, op. cit., p. 173.
} 
até 1734) e obteve provisões para se efectuarem as cerimónias de armar cavaleiro e recepção do hábito na Praça de Cachéu. ${ }^{61} \mathrm{O}$ filho, nascido em 1726, tornou-se num ainda mais poderoso proprietário rural e de escravos, com uma clientela que o transmutara em "régulo de Cabo Verde" e "Príncipe das ilhas". ${ }^{2}$ Não obstante o sangue mulato da mãe, sentia-se branco e como tal nascera, condição da qual se orgulhava. Ocupou os cargos camarários que tivera o pai, foi provedor da Misericórdia e capitão, coronel da milícia, ouvidor geral e governador interino do arquipélago.$^{63}$ Graças a serviços que apresentou como tendo sido de um tio afastado pelo lado materno, conseguiu também a mercê do hábito de Cristo. Tal como seu pai, nas habilitações respectivas, que terminaram em 1752, apenas enfrentou o embaraço das mecânicas do seu avô paterno. Dispensadas estas, conseguiu igualmente provisões para receber a insígnia em Cabo Verde. ${ }^{64}$ Em boa verdade, apenas teve sanções da Coroa quando foi acusado de conluio na morte do ouvidor geral de Cabo Verde, pois nessa ocasião levara muito longe o seu poder ${ }^{65} \mathrm{O}$ facto de ser filho de mulato não entravara o seu mando, nem mesmo para ser cavaleiro da Ordem de Cristo.

Em suma, em S. Tomé e Cabo Verde a realidade da cor da pele assumia outros contornos. Os negros e sobretudo os mulatos tinham acesso a cargos locais de forma menos restrita do que em territórios como o Brasil. A própria Coroa criava ali menos embaraços à promoção destes indivíduos. Mesmo nestas matérias havia um olhar quase hierárquico sobre o Império que também seria a pouco e pouco construído em função das oportunidades geradas no plano no regional.

\section{A apresentação de benefícios eclesiásticos}

Em matéria de provimentos eclesiásticos a cor da pele representaria algum tipo de entrave? Como actuaria a Coroa?

Na realidade esta última também intervinha na apresentação destes agentes, à sombra do padroado da Ordem de Cristo. Como é sabido, D. Manuel quando che-

\footnotetext{
${ }^{61}$ ANTT, Habilitações da Ordem de Cristo, Letra J, Mç. 92, doc. 34. ANTT, Chancelaria da Ordem de Cristo, Lo 221, fl. 10-11v.

${ }^{62}$ Iva Cabral, op. cit.

${ }^{63}$ Iva Cabral, op. cit.

${ }^{64}$ ANTT, Habilitações da Ordem de Cristo, Letra A, Mç. 47, doc. 71. ANTT, Chancelaria da Ordem de Cristo, Lo 264, fl. 223-224v.

${ }^{65}$ Iva Cabral, op. cit.
} 
gou ao trono manteve nas suas mãos aquele mestrado e o mesmo fez D. João III. Em 1551, com a anexação das três Ordens Militares à Coroa, o rei reforçou a sua posição; ganhou perpetuamente a qualidade de Mestre, ou mais correctamente de governador e administrador daqueles institutos e tinha já uma posição no padroado do Ultramar. Este era, no entanto, pouco efectivo para a Ordem de Cristo, como sempre o fora. Quem parecia beneficiar com isto era a realeza, enquanto tal e não exactamente o "Mestre" da Ordem. Explicitemos esta situação.

Bem vistas as coisas, pode essa história do padroado ultramarino ser resumida em três etapas fundamentais. Entre 1433 e 1454, foram confiados à Ordem de Cristo o espiritual de territórios muito específicos: Madeira (1433), Santa Maria e S. Miguel nos Açores (c. 1443) e Santa Maria de África (1443). Apenas entre 1454 e 1514 a Ordem dispôs de um padroado amplo, na sequência disputa luso-castelhana pelas Canárias e até pela conquista da Guiné. Foi neste contexto que, com esforço diplomático, foi alcançada a bula Inter cetera, de 1456. Por esta a Santa Sé outorgava perpetuamente à Ordem tomarense, a jurisdição espiritual sobre os territórios conquistados ou a obter dos Cabos Bojador e Não em diante até aos índios, ficando estas zonas nullius diocesis. Pela bula invocada, as terras sob a tutela religiosa da Ordem de Cristo atingiram a sua dimensão máxima e cabia ao Prior do convento prover os benefícios eclesiásticos, com cura ou sem cura de almas, seculares ou regulares, naquela vasta área. ${ }^{66}$

Na realidade, a Ordem de Cristo tinha um padroado que cresceu rapidamente e desde o início não tinha capacidade humana efectiva para o administrar. Não seria por mero acaso que desde 1454, os monarcas e o Infante D. Henrique estavam autorizados a enviar para fora do espaço metropolitano religiosos de qualquer ordem desde que tivessem licença do respectivo prelado. ${ }^{67}$

A partir de 1514 quase tudo mudou. Com a criação do bispado do Funchal, o bispo passava a ser da apresentação do rei e os capitulares do Mestre da Ordem de Cristo. Ensaiou-se uma solução que seria mais tarde aperfeiçoada, não obstante algumas hesitações. Quanto em 1533-1534, Cabo Verde, Angra, S. Tomé e Goa passaram a bispados, ao mesmo tempo que o Funchal foi elevado a arquidiocese,

\footnotetext{
${ }^{66}$ Publicação entre outros locais na Monumenta Henricina, vol. XII, Coimbra, Com. Exec. V Cent. Morte Inf. D. Henrique,1971, pp. 286-288.

${ }^{67}$ Definicoens e Estatutos dos cavalleiros, e freires da Ordem de Nosso Senhor Iesu Christo com a Historia da Origem e principio della, Lisboa, Ioam da Costa, 1746 ( $1^{\text {a }}$ ed. 1628), parte III, tít. XII, $\$ 4$.
} 
a bula funchalense de 1514 serviu de modelo. O monarca ficou incumbido de apresentar os prelados, na qualidade de rei.

Entretanto, o Convento de Tomar fora reformado a mando de D. João III, entre 1529 e 1530. Os antigos conventuais saíram e os 12 que ingressaram passaram a monges, com obrigação de clausura. Assim, mais do que nunca, esta parcela de religiosos da Ordem de Cristo ficara impossibilitada de disputar os benefícios eclesiásticos do padroado ultramarino. Seriam franciscanos e outras Ordens religiosas a exercê-lo.

Com a criação da diocese de S. Salvador da Baía, em 1551, consagrou-se definitivamente o duplo padroado que se ensaiara em 1514, régio e magistral, como apropriadamente lhe chamou Charles-Martial de Witte. ${ }^{68}$

Na prática, os monarcas passaram a delegar nos prelados a nomeação dos clérigos da respectiva diocese, incluindo as conezias e dignidades do cabido, excepto o lugar de deão. Cada novo bispo, uma vez a cumprir a sua obrigação de residência no território do seu bispado, devia solicitar ao monarca tal poder. Como eram lugares do padroado da Ordem de Cristo, cabia à Mesa da Consciência opinar a este respeito ${ }^{69}$ Quando o bispo escolhia alguém, a carta de apresentação era depois emitida em nome do rei, como Mestre. Tais poderes de confirmação podiam, inclusive, ser delegados no governador, como forma de agilizar os procedimentos.

Quando um deado era declarado vago, abria-se um concurso em Lisboa. Para o efeito, colocavam-se editais nas Universidades de Coimbra e Évora e na porta da Mesa da Consciência, de forma a captar candidatos. Havia depois exames e uma consulta de apreciação dos resultados e de hierarquização dos pretendentes naquela Mesa. Esse documento ia depois ao monarca na qualidade de Mestre para remate e nomeação da pessoa.

Em regra, apenas as vacaturas de cónegos e dignidades que ocorriam durante o período de sede vacante tinham concursos efectuados em Lisboa, nos termos descritos.

Nas mesmas circunstâncias, os cabidos faziam os concursos para as vigararias e benefícios curados, embora viessem a Lisboa para o apuramento final. Assim foi estabelecido em Março de 1651 porque anteriormente eram feitos em

\footnotetext{
${ }^{68}$ Les lettres papales concernant l'expansion portugaise au XVIe siècle, Immense, s.n., Les Cahiers de la Nouvelle Revue de Science Missionaire, nº XXXI, 1986, p.111.

${ }^{69}$ Veja-se um exemplo: ANTT - MCO - Ordem de Cristo - Padroados do Brasil, Mç. 4 (pedido de D. Fr. António de S. José, Bispo do Maranhão, consultado em 1756).
} 
Lisboa. ${ }^{70}$ Deste modo, na falta do bispo ou arcebispo, apenas os curatos anuais estavam dispensados desta última formalidade. ${ }^{71}$

Também se tornou norma que nos bispados recém-criados a primeira nomeação das dignidades do cabido fosse do rei; a delegação de competências no prelado (excepto para o deão) ocorreria apenas em relação às vacaturas seguintes. ${ }^{72}$

A partir do momento em que os bispos ultramarinos passaram a apresentar os clérigos, nomearam dominantemente seculares (ao contrário do se fazia até então) e estava criada a porta para serem colocados os sacerdotes locais, com todas as implicações daí decorrentes. $\mathrm{O}$ atributo do colorido da pele era uma delas.

$\mathrm{E}$ de facto havia clérigos mamelucos e mestiços em diferentes pontos do Brasil, embora não lhes fosse fácil a ascensão na hierarquia da Igreja.

Algumas barreiras seriam forjadas no contexto local e muitas vezes começavam no acesso às escolas. Estas discriminações tornaram-se mais evidentes a partir do final de Seiscentos.

No último quartel do século XVII, segundo explicou o Padre António Vieira, no Brasil, os brancos de maior estatuto não toleravam que nas escolas jesuíticas os seus filhos se sentassem ao lado dos mestiços. Tal facto levara a que fossem repudiados dos colégios da Companhia, mas - segundo opinava o mesmo parecer - que "readmitiriam estudantes de cor se recebessem instruções para o fazer da Coroa e do seu Geral".73

Em 1730, por exemplo, foram dificultadas as entradas para a Irmandade de São Pedro dos Clérigos do Recife. Os corpos directivos e os irmãos optaram pela exclusão dos que tivessem casta de pardo até o quarto grau. Apesar de tal ostracismo não ter sido facilmente aceite, foi novamente confirmado em 1739 e eram os próprios membros locais a corroborar essa atitude de repúdio. ${ }^{74}$

Globalmente, no clero paroquial da América Portuguesa, a situação seria semelhante ao que se passava com a obtenção de postos seculares: as elites locais

\footnotetext{
${ }^{70}$ BNP, Pomb., 155, fl. 13v.

${ }^{71}$ BNP, Cód. 10887, p. 430-430v.

${ }^{72}$ ANTT, Mesa da Consciência, Lo 304, fl. 17-17v.

${ }^{73}$ C. R. Boxer, op. cit., p. 116.

${ }^{74}$ Gustavo Augusto Mendonça dos Santos, Suely Creusa Cordeiro de Almeida, "O Clero secular: a formação de um clero mestiço em Pernambuco no século XVIII", texto disponível on-line em: http://www.cerescaico.ufrn.br/mneme/anais/st_trab_pdf/pdf_st3/gustavo_santos_st3.pdf, consultado em 09 de setembro de 2010.
} 
terão sido as primeiras a criar entraves aos de pele colorida, como forma de afirmar o seu estatuto à escala onde actuavam.

Noutros territórios do Atlântico, onde a percentagem de população de origem africana era elevada, também a gente de cor conquistava muitos desses lugares. S. Tomé constituía um espaço singular. Quase desde o início da colonização foram enviados para essa Ilha padres negros. Alguns foram recrutados entre os congolenses que se formaram em conventos de Lisboa. ${ }^{75} \mathrm{Em}$ Cabo Verde, na Ilha de Santiago, o Padre António Vieira constatava, em 1652, a inexistência de religiosos e como alguns clérigos e cónegos eram "tão negros como azeviche; mas tão compostos, tão autorizados, tão doutos, tão grandes músicos, tão discretos e bem morigerados, que podem fazer invejas aos que lá vemos nas nossas Catedrais". ${ }^{76}$

Nos espaços atlânticos, excluindo os bispos, a elite do clero seria constituída pelos cabidos catedralícios, em especial as dignidades, e os agentes do aparato institucional diocesano. Como se demonstrou, era no quadro dos Cabidos que a Coroa mais intervinha, efectuando a apresentação. Nestes universos, em geral os lugares iam parar às elites brancas, quase sempre reinóis. Mesmo em S. Tomé, no século XVI, seriam maioritariamente do Reino, embora houvesse uma ou outra excepção. ${ }^{77}$ Apenas na Madeira, o único local onde havia seminário a funcionar com regularidade desde o último quartel de Quinhentos, muitos eram naturais, a julgar pelo que acontecia no final do século XVII e primeira metade da centúria seguinte.

Nos espaços extra-europeus, um dos grandes problemas era - desde o século XVII - a concorrência dos naturais do reino, fosse para lugares de vigários ou inferiores ou para as conezias e dignidades. Quando os concursos se efectuavam em Lisboa (grosso modo até 1651), nos copiosos períodos de sede vacante, maior era o risco de defraudar os que haviam nascido nas ilhas e conquistas.

Desde o século XVII, havia reivindicações locais no sentido de ser dada preferência aos nascidos na terra. Assim o fez a Câmara da Ilha cabo-verdiana de

\footnotetext{
${ }^{75}$ Padre António Lourenço Farinha, A expansão da fé: na África e no Brasil (subsídios para a História Colonial), vol. I, Lisboa, Divisão de Publicações e Biblioteca - Agência Geral das Colónias, 1942, p. 119.

${ }^{76}$ J. Lúcio de azevedo, Cartas do Padre António Vieira, I, Coimbra, 1925, p. 294-298, apud Padre António Brásio, op. cit., 2a série, vol. VI, p. 24-25.

${ }_{77}$ Padre António Brásio, Para a história do Cabido de Angola e Congo, Lisboa, Agência Geral das Colónias, 1943 (Separata do Boletim Geral das Colónias, n² 210), pp. 9-11.
} 
Santiago e foi atendida em $1608 .^{78}$ Do Brasil também vieram apelos no mesmo sentido. A Coroa em 1679 foi favorável aos moradores do Rio de Janeiro "para que os filhos dos moradores daquella capitania prefiram nos postos da milícia, ofícios de justiça e fazenda e dignidades eclesiásticas aos destes Reinos, concorrendo neles os merecimentos e requisitos necessários" ${ }^{79}$ Estas exigências minoraram a questão, sem a erradicar. Em Cabo Verde, por exemplo, o clero paroquial do século XVII passou a ser maioritariamente autóctone e composto por muitos mestiços e até negros. ${ }^{80}$

$\mathrm{O}$ facto de muitos postos serem decididos em Lisboa, onde outros eclesiásticos se podiam candidatar, mesmo que o concurso fosse efectuado no Brasil, na Madeira ou noutro território fora do espaço continental europeu, representava um entrave também por duas razões, além da já aduzida. Por um lado, muitos clérigos vinham para Lisboa para poderem prestar provas e acompanhar os procedimentos, o que não era conveniente ao pastoreio dos seus fiéis, caso os tivessem; por outro, havia queixas que muitos criminosos eram, em Lisboa, providos como se fossem pessoas dignas, exactamente pela sua trajectória de vida ser menos conhecida. ${ }^{81}$ A tudo isto acrescia o facto destes lugares na sua génese pertencerem a uma Ordem Militar e como tal não se lhe aplicavam rigorosamente as normativas tridentinas. Queria isto dizer que o rei enquanto mestre não era obrigado a acatar os resultados do concurso, nem sequer a fazê-lo. Além dos resultados do exame, também contavam os serviços que o oponente arrolava nos seus requerimentos. Quer a Mesa da Consciência quer o monarca estavam atentos a esses desempenhos no pelouro eclesiástico, mas não só. Podiam contar os de parentes efectuados na guerra, por exemplo.

O alvará de 29 de Agosto de 1766 representou um marco importante, pois obrigava nos concursos a dar prioridade aos nascidos na diocese para a qual se destinava o cargo, mesmo perante a desigualdade dos restantes requisitos. A partir do citado alvará, tornaram-se mais evidentes as questões relacionadas com

\footnotetext{
${ }^{78}$ Maria Emília Madeira Santos, Maria João Soares, "Igreja, missionação e sociedade”, In: História Geral de Cabo Verde, cit., II, p. 400, 420.

${ }^{79}$ André João Antonil, Cultura e opulência do Brasil por suas drogas e minas, Lisboa, CNCDP, 2001, pp. 334-335.

${ }^{80}$ Maria Emília Madeira Santos, Maria João Soares, op. cit., pp. 421, 475-481.

${ }^{81}$ BNP, Pomb., 155, fl. 13v.
} 
o cromatismo da pele, inclusive nos postos mais relevantes da hierarquia eclesiástica, uma vez que o documento em causa também se aplicava aos cabidos e respectivas dignidades. Mesmo assim, pela investigação disponível é importante precisar que o documento em causa abriu mais facilmente as portas aos homens de cor de S. Tomé e de outros territórios onde havia já uma tradição de capitulares não brancos, do que no Brasil, por exemplo.

No entanto, de S. Tomé e Angola nem sempre havia naturais aptos a concorrer a estes lugares. Muitas vezes pela falta de candidatos, fosse qual fosse a sua origem, os lugares ficavam vazios ${ }^{82}$ ou eram providos em minoristas na segunda metade do século XVIII. ${ }^{83}$

Nestes concursos por vezes a cor era referida, mas nem sempre. Pelo que ficou registado na pouca documentação que hoje sobrevive das apresentações destes lugares, nota-se claramente que a cor da pele pragmaticamente pouco contava, sobretudo se se destinassem a Cabo Verde, Angola ou S. Tomé.

No entanto, a nível local, a recepção dos indigitados nem sempre foi pacífica. Podem apontar-se diversos exemplos de problemas em S. Tomé e Angola. Por exemplo, em S. Tomé, em 1671, os pardos ou miscigenados do Cabido da catedral não viram com bons olhos a chegada de um prebendado negro e foi necessário que o rei pedisse a intervenção do Governador e Ouvidor; em 1707, surgiram novas desavenças neste mesmo Cabido entre cónegos negros, pardos e brancos, tendo os segundos solicitado ao monarca que não indigitasse mais negros. ${ }^{84} \mathrm{Tam}$ bém no arquivo da Mesa da Consciência ficou um registo de 1679, respeitante a Angola. O bispo reclamou que Sua Majestade elevara a cónegos gente criminosa, mulata e um deles cristão-novo. A Mesa da Consciência terá retorquido que fizera as habilitações usuais e que não detectara máculas e "que ser mulato não era impedimento". Face a este veredicto foi executado o provimento. ${ }^{85}$

${ }^{82}$ Dois exemplo entre muitos para S. Tomé: ANTT, Mesa da Consciência, Lo 319, fl. 107-107v, $114 \mathrm{v}-115$.

${ }^{83}$ Alguns exemplos: AHU, Conselho Ultramarino, Lo 944, fl. 17, 39; ANTT, Mesa da Consciência, Lo 319, fl. 45v-46.

${ }^{84}$ Padre António Lourenço Farinha, op. cit., pp. 143-144.

${ }^{85}$ BNP, Pomb., 155, fl. 14. 


\section{Distinções e cor da pele}

Como é sabido, na sociedade ibérica o estigma da "mancha de sangue" pendeu fortemente sobre os cristãos-novos de origem judaica ou muçulmana. Quando em 1570, através da bula Ad Regie Maiestatis, de 18 de agosto, foram introduzidos estatutos de limpeza de sangue nas três Ordens Militares portuguesas, apenas se aludia à exclusão de mouros e judeus, sem mencionar outro tipo de sangue. ${ }^{86} \mathrm{O}$ mesmo acontecia nos Regimentos do Santo Ofício de $1552,{ }^{87} 1613^{88}$ e $1640 .^{89}$

No entanto, numa habilitação da Ordem de Cristo de 1615, o interrogatório já mandava inquirir, "se por parte de seu pai mãe e avós tem alguma raça de cristãonovo, mouro, judeu, ou gentio ou fama disso (...)". ${ }^{90}$ Era um questionário manuscrito enviado ao bispo do Funchal e talvez seja o mais antigo que se conhece, pois a quase totalidade das habilitações do final do século XVI e inícios do XVII perdeu-se. Naquela data, já se incluíam os gentios no rol dos impuros. Não se tratava de perguntar pela cor da pele, mas sim pelo tipo de sangue, classificando-o este com uma grelha essencialmente religiosa. Mesmo quando na época se usava a expressão "raça", Bluteau, no princípio do século XVIII, esclarece que se dava ao vocábulo dois sentidos: um de casta que se reportava a animais irracionais, como cavalos e cães; outro, a gerações. Nesta última acepção sublinhava "se toma sempre em má parte. Ter Raça (sem mais nada) val o mesmo, que ter Raça de Mouro, ou Judeo". Para tornar tudo mais explícito dava o exemplo do Compromisso da Misericórdia de Lisboa, onde se escrevera, a páginas 26v: "Procurarseha, que os servidores da Misericordia não tenhão Raça." "Raça" valia como um todo, mas esse todo não abarcava os gentios, negros ou mulatos.

Os negros africanos, tal como os autóctones ameríndios, não seguiam nenhuma das grandes religiões com as quais se confrontava a Católica, que eram o Judaísmo e o Islamismo. Por esse facto, constituíam uma espécie de neutro reli-

\footnotetext{
${ }^{86}$ Corpo Diplomatico Portuguez contendo os actos e relações politicas e diplomaticas de Portugal com as diversas potencias do mundo desde o seculo XVI até os nossos dias, ed. de José da Silva Mendes Leal, t.XI, Lisboa, Typ. da Academia Real das Sciencias, 1898, p. 633.

${ }^{87}$ Cap $^{\circ} 23$, cap $^{\circ} 41$, cap $^{\circ} 68$, cap $^{\circ} 130$.

${ }^{88}$ Título IV, cap ${ }^{\circ}$ XII; Título XIII, cap ${ }^{\circ}$; Título XVI, capo I; Título XVII, capos I, IV e V.

${ }^{89}$ Livro I, título I, $\$ 2$.

${ }^{90}$ ANTT, Habilitações da Ordem de Cristo, Letra J, Mç. 4, doc. 5.

${ }^{91}$ Vocabulario Portuguez, \& Latino, t.VII, Lisboa, na Off. de Pascoal da Sylva, 1720, sub voce "Raça".
} 
gioso, que idolatrava deuses pagãos. Como não tinham uma adesão a um credo religioso estruturado que houvesse que combater; bastava ensinar-lhes os preceitos católicos, doutriná-los. No embate entre as grandes religiões, o seu lugar era menos embaraçoso. Ficavam na categoria "gentios", não obstante muitos serem considerados "peças" transaccionáveis, como outros bens. Esta interpretação estava manifesta em Zurara, na Crónica da Guiné, num pequeno episódio que se reportava a pouco depois de 1441. Segundo escrevia, um mouro, trazido por Antão Gonçalves e Nuno Tristão como cativo solicitara ao primeiro que o colocasse na sua terra e que lhe daria em compensação outros 10 nativos. De acordo com a mesma crónica, Antão Gonçalves explicou ao Infante D. Henrique a vantagem do pacto, nestes termos: “... E que melhor era salvar dez almas que tres, que pero negros fossem, assim tinham almas como os outros, quanto mais que estes negros não vinham da linhagem de Mouros, mas de gentios, pelo qual seriam melhores de trazer ao caminho da salvação." ${ }^{92}$ Neste quadro cultural e ideológico era mais benevolente ser gentio do que ser infiel, apóstata ou herege.

Terá sido no começo do século XVII, quando os estatutos de limpeza de sangue se cimentavam em Portugal, que o ser de cor foi transposto para os sistemas de exclusão social assentes em habilitações. Aos dois tipos de sangue repudiados juntou-se mais um, sem plena equivalência de estatuto. Como amplamente demonstra Francis A. Dutra, os negros e mulatos, o sangue de herança africana, se não tivesse notas de cristã-novo era considerado puro na Mesa da Consciência. ${ }^{93}$ Faça-se notar que nas Ordens Militares portuguesas, os monarcas nunca delegaram em Roma o poder de dispensar este tipo de sangue, como o fizeram em relação ao judaico e muçulmano. Não seria por acaso. Não o tomariam no mesmo pé e interessava-lhe poder controlar as excepções nesse campo, tendo em vista as amplas periferias coloniais da Monarquia. Era exactamente este tipo de pragmatismo do zelar pelos interesses nem sempre consentâneos que levava a que na atribuição de cargos, ou na gestão dos conflitos, houvesse assinalável flutuação de atitudes: ora favoráveis a gentes de cor, ora desfavoráveis.

${ }^{92}$ Crónica de Guiné, introd., notas, novas considerações e glossário de José de Bragança, s.l., Liv. Civilização, [imp. 1973], cap. XVI, p. 86.

93 "African heritage and the Portuguese Military Orders in seventeenth - and early eighteenth-century Brazil: the case of Mestre de Campo Domingos Rodrigues Carneiro", Colonial Latin American Historical Review, 15:2, 2006, pp. 116, 131, 135-136, 13-140. Ver também o seu artigo neste dossiê. 
No caso do Santo Ofício, a exclusão dos gentios foi um pouco mais tardia, talvez próxima da década de 1640 (com a investigação disponível, não é possível apontar uma cronologia mais precisa). Era, no entanto, o tribunal que a sociedade da época considerava o mais rigoroso em matéria de classificações sociais. As suas práticas e veredictos seriam marcantes na ambiência político-ideológica coeva. Importará trazê-los à colação.

Ali, pelo que a pesquisa acumulada permite observar, o sangue mulato não era dos mais presentes, mas também não foi dos mais castigados pela rejeição, a despeito de alguns picos cronológicos. Estes últimos devem ser analisados em função de contextos específicos e não tomados como regra geral. ${ }^{94}$ Sem dúvida que a genealogia judaica ou cristã-nova era ostensivamente a mais visada, não obstante a existência de diversas excepções a gente com antepassado judeus. ${ }^{95}$ Aliás, em 1748, o médico António Ribeiro Sanches (1699 - 1783) notou que "vemos todos os dias a raça de negro e mulato extinguir-se em quatro gerações, e no fim delas todos vêm a ser Portugueses". Ciente dessa suposição, exortava: "Faça-se, pelo amor de Deus, do mesmo modo com os X. N.s [cristãos-novos], como se faz com os negros" ou seja que "que em três, ou quatro gerações, se acabem os Judeus e o Judaísmo".96

Com efeito, com o sangue africano e autóctone, por essa época já se atenderia muito ao facto da mácula se situar dentro ou fora do $4^{\circ}$ grau. Transposta a barreira geracional apontada, o problema não suscitava grandes obstáculos.

Nos séculos XVII e XVIII, tendencialmente, a existência de gotas de sangue negro, sobretudo se imprecisas, tendiam a ser desvalorizadas pelos tribunais que alicerçavam as classificações sociais do centro político metropolitano.

A dualidade de critérios no seio destas instituições podia projectar-se, até, no capítulo das evidências. Assim, se no decurso de um testemunho o depoente estabelecesse uma correspondência entre atributos físicos (tez trigueira, nariz chato,

\footnotetext{
${ }^{94}$ Situação que poderá potenciar alguns equívocos, como, por exemplo, em Isabel Drumond Braga, "A Mulatice como Impedimento de acesso ao "Estado do Meio"', In: Actas do Congresso Internacional Espaço Atlântico de Antigo Regime: poderes e sociedades, Lisboa, FCSU/ UNL, 2005.

${ }^{95}$ João de Figueirôa-Rêgo, A honra alheia por um fio: os estatutos de limpeza de sangue no espaço de expressão Ibérica (séc. XVI-XVIII), Braga, Dissertação de doutoramento em História Moderna, apresentada à Universidade do Minho, 2009.

${ }^{96}$ António Ribeiro Sanches, Cristãos Novos e Cristãos Velhos em Portugal, Covilhã, Universidade da Beira Interior, 2003, p. 10. Agradece-se a Aldair Rodrigues esta referência.
} 
beiços largos ou cabelo encarapinhado) e impureza, sem que existisse prova irrefutável, a observação era em geral desvalorizada ${ }^{97}$ Ao contrário, quando o defeito era sugerido sem ser estabelecida qualquer marca fisionómica, os ministros do Santo Ofício atenuavam a nota, com base na inexistência de características étnicas notórias, ${ }^{98}$ as quais, a existirem, não teriam deixado de ser referidas, conforme frequentemente asseveravam os magistrados. Desde que estivessem preenchidos alguns requisitos (é certo que variáveis em função dos ritmos da Inquisição), a existência de sangue moderadamente negro não constituiu, como já foi pretendido, "um empecilho praticamente intransponível" para aceder a posições de estima. ${ }^{99}$ Fossem as derradeiras consubstanciadas numa carta de familiar ou na provisão de notário, ou ainda, de comissário do Santo Ofício. Assim sucedeu, por exemplo, com Agostinho Medeiros Ferreira, presbítero do hábito de S. Pedro. Habilitou-se para servir a Inquisição, mas no decurso da investigação houve nota de mulatice. ${ }^{100} \mathrm{O}$ alegado defeito foi considerado improcedente e ao clérigo passada provisão de notário do Santo Ofício em 1743. ${ }^{101}$ Além de ter recebido benefícios em duas igrejas (uma das quais a Matriz de Ponta Delgada), por carta de apresentação da Ordem de Cristo. ${ }^{102}$ Nas habilitações do beneficiado e vigário da vara de Torres Vedras, Agostinho Nunes, prior encomendado da igreja de Sta. Maria do Castelo, a fama de mulatice, veiculada no inquérito, não lhe impediu a aprovação para comissário em 1649. ${ }^{103}$

Há ainda outros exemplos expressivos. O escrivão da Provedoria de Guimarães, Carlos António da Costa Cardoso, habilitou-se, em 1744-1745, para a Ordem de Cristo. ${ }^{104}$ No ano seguinte era aprovado apenas com dispensa de mecâ-

${ }^{97}$ Entre muitos outros ver ANTT, Habilitações do Santo Ofício, António, Mç. 13, doc. 473; ANTT Habilitações do Santo Ofício, António, Mç. 108, doc. 1886. Outro exemplo, relativo a um tesoureiro dos defuntos do Rio de Janeiro, em ANTT, Inquisição, Conselho Geral, Lo 35, fl.6v.

${ }^{98}$ ANTT, Habilitações do Santo Ofício, João, Mç. 52, doc. 994. Apesar de todas as testemunhas aludirem à mulatice do habilitando, a Mesa entendeu que este não tinha cara preta nem cabelo encarapinhado.

${ }^{99}$ Raimundo Agnelo Soares Pessoa, Gente sem sorte: os mulatos no Brasil colonial, Universidade Estadual Paulista, 2007.

${ }^{100}$ ANTT, Habilitações do Santo Ofício, Agostinho, Mç.4, doc. 65.

${ }^{101}$ ANTT, Inquisição de Lisboa, L ${ }^{\circ} 114$, fl.154v.

${ }^{102}$ ANTT, Chancelaria da Ordem de Cristo, Lo 197, fls. 239v, 384, 440.

${ }^{103}$ ANTT, Habilitações do Santo Ofício, Agostinho, Mç. 1, doc.11.

${ }^{104}$ ANTT, Registo Geral de Mercês, D. João V, Lo 33, fl. 38v; ANTT, Chancelaria da Ordem de Cristo, Lo 224, fl. 35-36v. 
nicas, porquanto de resto teria a limpeza necessária. Não teve dificuldade em alcançar esta distinção, apesar de: no Santo Ofício, do qual já era familiar, ter constado fama de mulatice, por via de uma avó (neta de escrava preta); ${ }^{105}$ a despeito da existência de inquirições contraditórias, feitas a parentes seus, de manter relações com uma mulher adúltera e infamada de mulata; de seu pai (que possuía uma taberna conhecida como "do Negro") ter sido rejeitado pela irmandade da Misericórdia da localidade e de no próprio se notar ainda cabelo carapinha. O seu processo de branqueamento e nobilitação começara em 1735, quando saiu habilitado pelo Desembargo do Paço, para os lugares de Letras. ${ }^{106}$

Idêntico no desfecho, embora com percurso inverso, foi o caso protagonizado por João Xavier Teles de Sousa em 1763. Filho de uma mulher com fama de mulata (por sua vez filha ou neta de uma escrava e do fundador do colégio da Companhia, em Portimão), peticionou a graça de ser dispensado do defeito, mas viu-se recusado. Porém, não desistiu do intento e o processo acabou, no ano seguinte, por subir de novo ao Conselho Geral do Santo Ofício que o aprovou. O próprio irmão do habilitando, clérigo do hábito de S. Pedro, foi dispensado no defeito para poder tomar ordens. Teles de Sousa, já possuidor da familiatura ${ }^{107}$ requereu, logo após, junto do Desembargo do Paço, a sua Leitura de Bacharéis, ${ }^{108}$ ultrapassada sem embaraços. Era o prólogo de uma carreira que o levaria a Desembargador da Casa da Suplicação, devidamente adornado com as insígnias da Ordem de Cristo.

Observe-se, contudo, que em matéria de gentilidade, o sangue cativo (escravo) era uma das notas que mais obstáculos acarretava. Veja-se a propósito o voto no Conselho Geral do Santo Ofício, na habilitação do Santo Ofício de António Vieira Rebelo e subscrito por Francisco António Marques Giraldes, em 1770: [a avó materna tem mácula de mulatismo] "Por descender de uma preta, que se ignora se foi escrava, e até o grau, em que principiou, sendo já fora do $4^{\circ}$ grau o que lhe dão algumas testemunhas nos quais termos e ainda na opinião dos mais escrupulosos que supõe defeito no mulatismo, que não sigo, mas sim a objecção da escravidão, ainda o verificar-se esta, seria em grau tão remoto, e se acha o habilitando no estado nobre de capitão, em que lhe não podia obs-

\footnotetext{
${ }^{105}$ ANTT, Habilitações do Santo Ofício, Carlos, Mç. 2, doc. 27.

${ }^{106}$ ANTT, Leitura de Bacharéis, Carlos, Mç. 3, no 38.

${ }^{107}$ De que prestou juramento, cf. ANTT, Inquisição de Évora, Lo 151, fl.19.

${ }^{108}$ ANTT, Leitura de Bacharéis, João, Mç. 23, nº 25.
} 
tar, como também a falta de notícia do avô materno (...) e de Manuel Ribeiro avô materno de sua mulher nas suas naturalidades, por serem bem reputados nos seus domicílios, e terem a seu favor a presunção de pureza, enquanto se não mostra o contrário." ${ }^{109}$ Eis como este capitão do Regimento de Artilharia da Praça de Estremoz chegou a familiar do Santo Ofício e como base nesta distinção a cavaleiro da Ordem de Cristo, ${ }^{110}$ apesar da fama de mulatice, com sinais evidentes no corpo. No caso, o elemento do Conselho Geral que analisou as diligências nem considerava o mulatismo defeito, mas sim o sangue cativo. $\mathrm{O}$ facto de o indivíduo ter atingido o posto de capitão (conseguiu-o no decurso da habilitação) não foi indiferente ao seu processo.

Todos estes casos, entre os muitos que se poderiam apontar, reportavam-se ao solo Metropolitano. Seriam diferentes se respeitantes ao Império?

Na realidade, os estudos recentes de Francis A. Dutra revelam que diversos mulatos extra-europeus receberam o hábito de uma Ordem Militar, sobretudo o de Santiago. Também provam que quando houve grandes entraves quase sempre não foi o monarca-Mestre a criá-los, mas sim a Mesa da Consciência. Para a Coroa, os imperativos conjunturais e os ditames da economia da mercê obrigavam a efectuar dispensas sobre riscos de não se garantir serviços. Na realidade, conclui que a questão nuclear para a reprovação de alguns negros não era a cor da pele, mas o facto de eles próprios ou os seus ascendentes imediatos terem sido escravos. ${ }^{111}$ É possível que, no início do século XVIII, a atribuição de mercês de hábitos a diversos negros por serviços militares no Brasil e os problemas levantados pelas consequentes habilitações tenham suscitado um debate mais alargado. De certa forma é o que se intui de testemunhos soltos posteriores, como os citados de Ribeiro Sanches e Francisco António Marques Giraldes.

Em 23 Janeiro de 1721, D. João V dispensou de inquirições para receberem as insígnias da Ordem de Santiago D. Sebastião Saraiva Coutinho, D. José Vasconcelos e D. Filipe de Sousa e Castro, índios da serra de Ibiapaba da capitania de Pernambuco. A Mesa da Consciência não levantou objecções por entender que, de acordo com os estatutos da Ordem, o Mestre (o Rei) podia eximir de

\footnotetext{
${ }^{109}$ ANTT, Habilitações do Santo Ofício, António, Mç. 172, doc. 26262, fl. 183v.

${ }^{110}$ ANTT, Habilitação da Ordem de Cristo, Letra A, Mç. 28, doc. 6.

${ }^{111}$ Francis A. Dutra, art. cit. e Idem, “To be a 'Mulato' in Early Modern Portugal”, Thirty-Ninth Annual Meeting of the Society for Spanish and Portuguese Historical Studies, Fort Worth, Texas, 5 Abril 2008.
} 
provanças os nomeados para hábitos, quando soubesse que tinham as qualidades necessárias. ${ }^{112}$ Não nos alongaremos em mais considerações no tocante aos ameríndios, porquanto a questão tem sido objecto de estudos recentes. ${ }^{113}$ Nos índios, note-se que nem a questão do sangue escravo se punha.

Houve, todavia, gente com sangue cativo dentro do 4 grau que foi dispensada. ${ }^{114}$ Os imperativos da economia da mercê por vezes falavam mais alto do que os preconceitos sociais.

No caso de S. Tomé houve até um comissário do Santo Ofício de cor negra. Em Novembro de 1774, quando deu início às diligências de habilitação apresentou-se de imediato como "homem preto" e pediu o cargo, alegando que não havia outro na Ilha. O Padre Manuel de Sousa Gonzaga das Mercês não era, todavia, um clérigo raso. Era Tesoureiro-mor da catedral de São Tomé e Comissário delegado da Bula da Cruzada; em 1780 serviu de visitador geral do bispado e de provisor do mesmo. O pai também era natural de S. Tomé e fora alferes e ajudante de infantaria, que viveu da ocupação de escrivão da ouvidoria da Ilha. Apenas o avô materno teria um estatuto mais baixo por ter sido alfaiate com tenda aberta na Ilha. Em 1783 teve as habilitações aprovadas. Demoraram alguns anos, mas tal circunstância não se deveu propriamente à cor da pele, mas sim ao facto de alguém ter referido que tinha uma filha. O elemento do Santo Ofício que fez o relatório da habilitação desde logo salientou que todos os naturais da terra eram "de cor preta, mas sem defeito algum". 115

\footnotetext{
${ }^{112}$ ANTT, Mesa da Consciência - Ordens Militares - Papéis Diversos, Mç. 20, macete 10.

${ }^{113}$ Ronald Raminelli, “Os Índios e a obtenção de hábitos das Ordens Militares”, comunicação apresentada ao VI Encontro sobre Ordens Militares, Palmela, 2010, também do mesmo autor: "Privilegios y malogros de la familia Camarão", Nuevo Mundo Mundos Nuevos, Coloquios, 2008, disponível on-line, URL: http://nuevomundo.revues.org/index27802.html. Consultado em 06 Março 2009; Idem, "Serviços e mercês de vassalos da América portuguesa", Historia y Sociedad, No. 12, 2006; Idem, "Mameluco, paulista e cavaleiro da Ordem de Cristo", In: Usos do Passado - XII Encontro Regional de História ANPUH-RJ, 2006, disponível on-line, URL: http://www.rj.anpuh.org/resources/rj/Anais/2006/conferencias/Ronald\%20Raminelli.pdf; consultado em 03 Dezembro de 2009; Idem, "A escrita e a espada em busca de mercê", In: Viagens ultramarinas: monarcas, vassalos e governo à distância, São Paulo, Alameda, 2008, pp. 17-60.

${ }^{114}$ Francis A. Dutra, “To be a 'Mulato' ...”, op. cit.; Júnia Ferreira Furtado, "Mulatismo, mobilidade e hierarquias nas Minas Gerais: os casos de Simão e Cipriano Pires Sardinha”, In: Raízes do privilégio: mobilidade social no mundo ibérico do Antigo Regime, org. por Rodrigo Bentes Monteiro, et al. (no prelo).

${ }^{115}$ ANTT, Habilitações do Santo Ofício, Manuel, Mç. 247, doc. 1543, fl. 31v.
} 


\section{Considerações finais}

Em suma, tais realidades não pretendem escamotear a existência de discriminação em função da cor da pele e de violência implícita a este respeito na sociedades portuguesas e nas das periferias coloniais. Ela existia e era um dado inquestionável, fosse em Lisboa, na Baía ou em Cabo Verde e S. Tomé.

A imagem da benevolência luso-tropicalista há muito que tem sido desconstruída. Não seria acidentalmente que o maior número de anedotas sobreviventes desta época dizia respeito a negros e mulatos e não tanto a cristãos-novos ou ainda a muçulmanos. ${ }^{16}$ Convém também salientar que se alguns nativos conseguiram o hábito de uma Ordem Militar muitas vezes não foi o de Cristo (o mais valorizado) e tal conquista em geral deveu-se a serviços muito excepcionais em conjuntura difíceis. Outro tópico a enfatizar é que nem sempre essas habilitações ou as de familiares foram processos rápidos e lineares. Foram longas e geradoras de muita ansiedade e vexame para os implicados. Todavia, a percentagem de processos bem sucedidos terá sido significativa, face ao número diminuto dos que logravam alcançar uma simples mercê deste teor.

Convém destacar o peso das clivagens construídas nas redes e contexto locais, como se tornou muito evidente em Minas na primeira metade de Setecentos. O dinamismo das periferias levava a que se forjassem distinções com os dispositivos simbólicos de mais imediata apropriação local como era a cor da pele.

A Coroa muitas vezes era a primeira a promover a discriminação, ao privilegiar a amiúde os reinóis nos provimentos seculares e eclesiásticos. Não era por acaso que na segunda metade do século XVII escrevia Gregório de Matos e Guerra: "Não sei, para que é nascer/ neste Brasil empestado/ Um homem branco, e honrado/ sem outra raça. / Terra tão grosseira e crassa/ que a ninguém se tem respeito, / Salvo quem mostra algum jeito/ de ser mulato." 117

A Coroa oscilava frequentemente nas suas posturas, quer de um território a outro, quer de época para época. Em S. Tomé, por exemplo, valia quase tudo para manter o seu domínio, fosse em matéria de provimentos seculares ou eclesiásticos. Por fim, saliente-se que onde a Coroa era aparentemente mais tolerante, nem sempre essa atitude promovia menor conflitualidade local.

\footnotetext{
${ }^{116}$ Francisco Bethencourt, “Anedotas e racismo em Portugal no século XVI", In: A Primavera toda para ti: homenagem a Helder Macedo, ed. Margarida Calafate Ribeiro, et al., Lisboa, Presença, 2004, p. 134.

${ }^{117}$ Obras Poéticas, Rio de Janeiro, Record, 1992, p.1164.
} 
Faça-se notar ainda que o monarca, em geral, fosse no papel de Mestre ou outro em geral manifestava gestos de benevolência e de paternalidade. Assim o obrigava a cultura política dominante no período Moderno, alicerçada nos princípios da economia da mercê, da desigualdade e do privilégio. No entanto, essa não deixava de ser uma forma de exercer poder, numa monarquia pluri-continental - como lhe chamou Nuno G. Monteiro - de forma a captar, se necessário, os serviços de um nativo. Era, todavia, na concretização das recompensas, que se jogava o peso das instituições e das discriminações incorporadas pelos grupos sociais. Não seria por acaso que o defeito de sangue escravo se tivesse tornado tão difícil de ultrapassar, sobretudo a partir do patamar das distinções intermédias do centro político como eram os hábitos das Ordens Militares. Mesmo para o provimento de lugares de clérigo no Brasil (Minas Gerais) podia causar embaraços no último quartel do século XVIII, até para quem tinha passado pela Universidade de Coimbra. ${ }^{118}$ Deste ponto de vista, o seu peso em pleno século XVIII aproximava-se da mácula de sangue cristão-novo. Quando aquela caiu oficialmente em 1773, a outra persistiu pelo menos para quem o tinha nas 4 gerações e não dispunha de boas redes de influência. Enfim, será importante que as pesquisas futuras tenham em conta esta variável de modo a firmar ou rebater tal hipótese.

${ }^{118}$ Júnia Ferreira Furtado, op. cit.. 